A REVIEW :

Article Chronicle:

Received :

13.07.2017;

Accepted :

28.07.2017

KEY WoRDS :

Silicon, Heavy metal, Field crops, Soil

\section{Interection of silicon on heavy metal and other stresses in crop plants}

\section{RAKESH SIL SARMA, SRINIVASA REDDY YERVA, GOURI SHANKAR PANDA AND CHANDAN MAHARANA}

SUMMARY : Silicon is the most aboundant element in soil and is beneficial for a large variety of plants. It is concentrated in plant tissues in quantities similar to that of macronutrients. Considerable damages to plants caused by abiotic stresses such as drought stress, salinity stress, heavy metal stress and nutrient imbalance, as well as biotic stresses like insect pests and pathogens and even herbivorous attacks, have been reported to be reduced significantly by silicon application. Soil contamination with toxic heavy metals (such as $\mathrm{Cd}, \mathrm{Pb}, \mathrm{As}, \mathrm{Hg}, \mathrm{Zn}$ ) is becoming a most devasting problem worldwide because of the rapid development of social economy. Silicon significantly improved the growth and biomass of crop plants and reduced the toxic effects of heavy metals after different stress periods. Si treatment ameliorated root function and structure compared with non-treated crop plants, which suffered severe root damage. Silicon plays a substantial role in alleviating heavy metal toxicity in crop plants. Also, silicon may reduce the toxic effects of heavy metals in soil. It may protect the foliage and increase light uptake and reduce respiration. Therefore, in this review, we discussed the effects of silicon on heavy metal stress in especially field crops.

How to cite this article : Sarma, Rakesh Sil, Yerva, Srinivasa Reddy, Panda, Gouri Shankar and Maharana, Chandan (2017). Interection of silicon on heavy metal and other stresses in crop plants. Agric. Update, 12(TECHSEAR-3) : 883-887; DOI: 10.15740/HAS/AU/12.TECHSEAR(3)2017/883-887.
Author for correspondence :

\section{RAKESH SIL SARMA}

Department of Plant Physiology, Institute of Agricultural Sciences, Banaras Hindu University, VARANASI (U.P.) INDIA

Email : sarmarakesh24@ gmail.com

See end of the article for authors' affiliations 